\title{
Authorities and Polish Exiles in the Siberia of the 19th century (Based on Epistolary Sources)
}

\section{Vladimir N. Shaidurov (a) \& Tadeush A. Novogrodski (b)}

(a) Pushkin Leningrad State University. St. Petersburg, Russia. Email: s-w-n[at]mail.ru

(b) Belarusian State University. Minsk, Belarus. Email: tadeush_minsk[at]mail.ru

\begin{abstract}
The Polish movement of national liberation is one of the characteristic features of the history of the Russian Empire in the nineteenth century. Tsarism reacted harshly to the uprising in Poland in 1830-1831 and the January Uprising of 1863-64. Plenty of participants were exiled under police supervision to the inner provinces of European Russia and Siberia. Correspondence became the main channel of communication for the exiles and their loved ones. Additional rules were developed at the end of 1863 in order to strengthen control over the exiled Poles, which included perlustration of postal and telegraphic correspondence by the provincial and county authorities. The purpose of the study is to analyze the extracts and copies of the letters of Polish exiles which are preserved in the State Archive of the Novgorod region and deal with the Siberian theme. The detected documents contain information that makes it possible to reconstruct certain aspects of the daily life of Poles on the way to the exile location and in the new place of their residence, to describe the moods of the exiles and their attitudes towards the events of national and local significance as well as to present individual plots of family history. The article is intended for those interested in genealogy, the history of Polonia in Russia, perlustration in the Russian Empire and the daily life of exiles.
\end{abstract}

Keywords

Perlustration; Police Supervision; Exile; the January Uprising of 1863-1864; Novgorod Province; Siberia; Alexander II; Stefania Piottukh; Everyday Life

This work is licensed under a Creative Commons "Attribution” 4.0 International License 


\section{Власть и ссыльные поляки в Сибири XIX в. (по материалам эпистолярных источников)}

\section{Шайдуров Владимир Николаевич (a), Новогродский Тадеуш Антонович (b)}

(а) Ленинградский государственный университет им. А.С. Пушкина. Санкт-Петербург, Россия. Email: s-w-n[at]mail.ru

(b) Белорусский государственный университет. Минск, Беларусь. Email: tadeush_minsk[at]mail.ru

\section{Аннотация}

Одной из характерных черт истории Российской империи в XIX в. стало польское национально-освободительное движение. Царизм жестко отреагировал на восстание в Польше в 1830-1831 гг. и Январское восстание 1863-1864 гг. Многие участники были сосланы под надзор полиции во внутренние губернии Европейской России и Сибирь. Переписка для ссыльных и их близких стала основным каналом связи. Для усиления контроля над ссыльными поляками в конце 1863 г. были выработаны дополнительные правила, включавшие перлюстрацию почтовой и телеграфной корреспонденции со стороны губернских и уездных властей. Целью исследования является анализ сохранившихся в Государственном архиве Новгородской области экстрактов и копий писем польских ссыльных, в которых присутствует сибирская тематика. Выявленные документы содержат информацию, позволяющую реконструировать отдельные аспекты будней поляков на пути к месту ссылки и на новом месте жительства, охарактеризовать настроения среди ссыльных и их отношение к событиям общегосударственного и местного значения, представить отдельные сюжеты семейной хроники. Статья рассчитана на тех, кто интересуется генеалогией, историей полонии в России, перлюстрацией в Российской империи, повседневной жизнью ссыльных.

\section{Ключевые слова}

перлюстрация; полицейский надзор; ссылка; Январское восстание 1863-1864 гг.; Новгородская губерния; Сибирь; Александр II; Стефания Пиоттух; повседневная жизнь

Это произведение доступно по лицензии Creative Commons “Attribution” («Атрибуция») 4.0 Всемирная 


\section{Введение}

Одним из результатов подавления Январского восстания 1863-1864 гг. стали многочисленные судебные процессы. Осужденные высылались в так называемые внутренние губернии Империи на поселение. Около 16 тыс. участников восстания было выслано в Сибирь на каторгу и поселение. Зачастую осуждались целые семьи, ее членов отправляли в разные места под надзор полиции. Находясь в ссылке, они стремились сохранить контакты друг с другом. Этому способствовало сохраненное им право переписки. Анализ содержания экстрактов и копий писем, сохранившихся в российских архивах, свидетельствует о том, что письма старались писать как можно чаще. Ссыльные, находясь еще в пути к месту поселения, получали весточки от родных и друзей, о чем извещали их в ответных письмах. Следовательно, письмо стало основным источником информации. В то же время за ссыльными на поселении был установлен полицейский надзор. Со стороны властей осуществлялся тотальный контроль, распространенный и на частную переписку.

\section{Источники и методы}

В архивных фондах сохранились преимущественно экстракты писем, составленные жандармскими чиновниками, и лишь немногочисленные полнотекстовые копии писем. В нашем случае были использованы материалы из фонда Новгородского губернатора (Ф. 138) Государственного архива Новгородской области. На сегодняшний день нами выявлена новгородская коллекция писем (16 архивных томов), датированная 1863-1875 гг. Мы имеем дело с материалами, переведенными на русский язык. Адресанты предпочитали писать письма на польском языке. Для их перевода при канцелярии Новгородского губернатора Э.В. Лерхе состоял штабс-капитан Николай Леохновский (Ковалев, 2013, с. 49).

Основное внимание нами уделено тем материалам, в которых упоминается сибирская тематика. В распоряжении имеются письма адресантов из Тобольска, Томска, Красноярска, Петровского завода за 1864-1867 гг., адресаты которых в этот период находились на ссыльнопоселении в Новгородской губернии. Адресантами выступали как сами ссыльные, так и лица, по собственной воле отправившиеся в Сибирь вместе с родными и близкими.

Сохранившиеся документы позволяют реконструировать настроения, царившие среди поселенцев в первые годы отбывания ими ссылки и их родных, оставшихся на родине; выявить темы, привлекавшие их внимание; восстановить отдельные страницы семейной истории.

Помимо копий писем и их экстрактов были использованы иные документы из фондов Российского государственного исторического архива и Госу- 
дарственного архива Томской области. Они позволяют реконструировать систему перлюстрации переписки и судьбы отдельных фигурантов.

В теоретическом отношении мы базируемся на методике «Линии времени» (the Time Line), которая предполагает линейное выстраивание событий семейной истории. Этот подход был выработан М. Стэнтоном в начале 1990-х гг. (Stanton, 1992). Вышесказанное предопределило комплекс использованных методов (историко-сравнительный, проблемно-хронологический, археографический, генеалогический).

\section{Обсуждение}

В отечественной историографии нередко поднимался вопрос о контроле над политической ситуацией в Российской империи второй половины XIX - начала XX в. со стороны полиции. Рассуждая об истоках этого явления, ученые нередко обращаются к высказыванию шефа III Отделения Собственной Его Императорского Величества Канцелярии А.Х. Бенкендорфа: «Перлюстрация - это есть одно из главнейших средств к открытию истины; представляя, таким образом, способ к пресечению зла в самом его начале, она служит также указателем мнений и образа мыслей публики о современных происшествиях и о разных представительных мерах и распоряжениях».

Некоторые исследователи отмечают в своих работах, что «корреспонденты часто не догадывались о существовании перлюстрации или не придавали этому особого значения» (Любичанковский, 2009, с. 65). С подобным утверждением сложно согласиться в отношении ссыльных, которые по установившейся практике вели переписку через представителей местной администрации.

Подавляющая масса публикаций посвящена перлюстрированной корреспонденции эпохи революционных потрясений начала XX в. и Первой мировой войны (Любичанковский, 2009; Гончарова, 2008). Особняком стоят работы историков права, обращавшихся к различным аспектам перлюстрации в дореволюционной России (Аракелян, 2007; Кеклис, 2009; Бодунова, 2014).

Перлюстрация как одна из форм политического сыска и изучения общественных настроений нашла отражение и в исследованиях зарубежных авторов. Большинство из них, как и отечественные историки, обращаются к периоду нарастания революционных настроений в Российской империи (Schleifman, 1988; Zukerman, 1996; Daly, 1998; Lauchlan, 2002).

Письма политических ссыльных хорошо изучены исследователями. Они активно используются при написании научных трудов. Правда, мы не можем в полной мере распространить это утверждение на польских ссыльных. Упоминания о письмах польских ссыльных в историографии носят единичный характер (Путрова, 2017). 
Польские и российские историки знакомы с письмами, которые направлялись представителям власти на местах (губернатору, полицмейстеру и т.д.) (Алексеева, 2013, с. 84). Изучено эпистолярное наследие наиболее видных представителей польской ссылки середины 1860-х - 1880-х гг. (Ковалев, 2013; Sinko \& Shaidurov, 2021). Но письма рядовых поселенцев, разбросанных в середине 1860-х гг. по разным губерниям от Новгорода до Нерчинска, изучены крайне слабо. Именно эти документы личного происхождения могут быть использованы для получения информации, которая ранее находилась вне поля зрения ученых. Так, оставаясь в XIX в. одним из немногих доступных способов коммуникации, личная переписка, как справедливо отмечают некоторые исследователи, по-прежнему является важным источником по истории повседневной жизни ссыльных (Алексеева, 2013, с. 84).

Исходя из вышесказанного, следует обратить особое внимание на материалы перлюстрации корреспонденции ссыльных участников Январского восстания 1863-1864 гг. с родными и близкими.

\section{Перлюстрация в России в середине XIX в.}

Пораженные в гражданских и имущественных правах, польские ссыльные сохранили возможность вести переписку, чем они активно пользовались. Некоторые современные авторы считают, что данная категория была ограничена в праве корреспонденции (Алексеева, 2013, с. 84). Действительно, мы наблюдаем нарушение права тайны переписки, что можно расценивать как посягательство на личную жизнь, ведь она находилась под контролем жандармских и полицейских чиновников на местах, которые перлюстрировали письма и принимали решение, исходя из его содержания, о передаче его адресату. Сами адресанты нередко в корреспонденции упоминали факт корректуры писем (ГАНО, 1863-1864, л. 144).

Еще в первые годы правления Николая I законодательно была разрешено принимать письма от ссыльных, водворенных на поселение в Сибири. Эта норма регламентировалась высочайше утвержденном Положением Сибирского Комитета «О приеме на почте писем от ссыльных для отправления в Россию» от 7 мая 1826 г. (ПСЗ-ІІ). Этим же актом такого права были лишены приговоренные к каторжным работам. Аналогичная ситуация сохранялась и в последующие правления, с определенными трансформациями.

В условиях нараставшего революционного движения полиция следила за корреспонденцией лиц, «обнаруживших вредные политические стремления». Вплоть до 1864 г. в соответствии с действовавшими законами и 77 инструкции полиции почтовая переписка этих лиц оставалась неприкосновенной, но начальник полиции должен был вести контроль над тем, кому они пишут и в какие местности направляют письма (РГИА, 1863-1873, л. 5). Эта процедура, по мнению чиновников, оказывалась совершенно неудовлетво- 
рительной. В краткой записке конца 1863 г. указывалось, что «лица, высылаемые из Царства Польского и Западного края, продолжают вести преступные переписки и даже делать противуправительственные распоряжения» (РГИА, 1863-1873, л. 5 об.).

В конце ноября 1863 г. в своем отношении к Министру внутренних дел П.А. Валуеву Виленский генерал-губернатор М.Н. Муравьев высказал мнение о необходимости подвергать получаемую и отправляемую ими корреспонденцию предварительной цензуре (РГИА, 1863-1873, лл. 1-1 об.). К обсуждению этого вопроса был привлечен шеф III Отделения Собственной Его Императорского Величества канцелярии князь В.А. Долгоруков, который заявил, что «подобная мера может быть принята только с высочайшего соизволения» (РГИА, 1863-1873, л. 4 об.).

Вчерне процедуру перлюстрации прописали в декабре 1863 г. Было предложено почтовую и телеграфную переписку лицам, высланным под надзор полиции, вести в губернских городах с ведома губернатора, а в уездных - местных исправников. Почтовые конторы и телеграфные станции «все письма и депеши, получаемые на имя высланных под надзор полиции лиц и ими отправляемые, а представляют на предварительный просмотр... полицейского начальства» (РГИА, 1863-1873, лл. 7-7 об.). В первоначальном варианте такие меры предлагалось осуществлять не ко всем поднадзорным, «а только к тем из них, в отношении которых Начальством, определяющим высылку, будет признано необходимым, что и объявляется высылаемому лицу и сообщается Начальнику той губернии, куда высылается для исполнения» (РГИА, 1863-1873, л. 8). В значительной степени эта мера, выработанная в недрах МВД и согласованная с Почтовым Департаментом, дополняла высочайше утвержденное 26 апреля 1863 г. Положение Комитета Министров о наблюдении за корреспонденцией лиц, обнаруживших вредные политические стремления (РГИА, 1863-1873, л. 18). Де-факто эти нормы обрели силу закона 2 января 1864 г. (РГИА, 1863-1873, л. 32).

Реализация выработанных правил контроля над корреспонденцией вызывала у местных полицейских чиновников затруднения. Главным из них оказался польский язык, на котором велась переписка. Однако уже в середине марта 1864 г. усилиями Западного Комитета и МВД эту проблему решили. По предложению Комитета губернаторам вменялось в необходимость иметь «в своем распоряжении благонадежных чиновников, знающих польский язык, для просмотра корреспонденции» (РГИА, 1863-1873, л. 84). Такие чиновники, кроме прочего, должны были пользоваться особым доверием губернаторов «и быть близко им известны» (РГИА, 1863-1873, л. 84 об.). Таковым для новгородского губернатора Э.В. Лерхе стал упомянутый выше штабс-капитан Н.Е. Леохновский, происходивший из местных дворян. В короткое время нашли способ оплаты жалованья этих лиц. Западный Комитет был готов ежегодно выделять до 1 тыс. руб. на каждого из них. Эту позицию поддержал 
Александр II, утвердивший мнение Комитета 19 марта 1864 г. Правда, ежегодные выплаты в последующие годы составляли не более 600 руб. ежегодно, да и получали их из Государственного Казначейства с задержками.

\section{Жизнь польских ссыльных в письмах}

Таким образом, в короткое время был создан механизм контроля над перепиской ссыльнопоселенцев. Для затруднения коммуникации создавались формальные препоны, о которых встречаются упоминания в письмах. Так, Елена Вериго в своем послании матери от 12 апреля 1865 г. отмечала:

«С письмами нашими теперь большая беда. Имеют все назначать или отсылать в Новгород, а оттуда в Вильно и в другие стороны по адресам. Не имеют что делать, так изыскивают себе работы. Для избежания долгих хороводов прошу адресовать ко мне на имя Новгородской губернаторской канцелярии, за исключением писем с какой-нибудь посылкой» (ГАНО, 1865, л. 140).

Подобный адрес для отправки корреспонденции был распространен и в Сибири. В феврале того же года Франциск Далевский, находившийся в Петровском заводе, просил сестру «писать в Читу на имя г. губернатора Забайкальской области» (ГАНО, 1865, л. 32). Такое решение объяснимо: губернатор зачастую решал вопросы передачи писем ссыльному и приема от него ответной корреспонденции. Ссыльные в короткое время смогли сориентироваться в сложившейся ситуации, дабы ускорить процесс.

Письма, судя по жандармским экстрактам, содержали информацию о жизни родных и близких, погоде. В первые годы после восстания в них встречается информация о хозяйственных вопросах в имении. Так, в письме от 2 октября 1864 г., адресованном Любовицкому, упоминается дурная погода, которая стала причиной плохих сборов «хлеба, сена и огородных овощей» (ГАНО, 1863-1864, л. 141). В некоторых письмах встречается информация о найме нужных работников для уборки урожая.

Оставшиеся в Царстве Польском сообщали родным о своей жизни. Крайне примечательно письмо Ясинскому от его брата Станислава из Варшавы, датированное сентябрем 1864 г. В нем рассказывается о театральных новостях, об актерах, желании знакомых устраивать музыкальные вечера (ГАНО, 1863-1864, л. 155). Бурные события неудавшегося восстания остались в прошлом, и варшавская жизнь постепенно возвращалась в прежнее русло.

Однако корреспонденция свидетельствует, что Январское восстание внесло коррективы в повседневность. Так, в письме Платера из Варшавы в январе 1865 г. отмечается, что «общественная же жизнь... совершенно переменилась, лучший, аристократический класс живет скромно, мещанство же, доходившее когда-то до того, что выбивало стекла, теперь танцует на своих шпиц-ба.... Средний класс больше других посещает театр» (ГАНО, 1865, л. 17). 
Переписка между ссыльными (родственниками или друзьями) носила предметный характер. В некоторых письмах встречаются описания отношений с местными властями. Большое место уделяется повествованию о проезде к месту ссылки или каторги. По их содержанию можно восстановить скорбный путь. Сохранилось письмо Игнатия Калиновского к Эдуарду Юхневичу, датированное 21 июля 1864 г.:

«Дорогие наши дети и внучата!

По истине уведомляем вас о нашем назначении, то есть что я с матерью высылаемся на жительство в Пермскую губернию. Костась на шесть месяцев арестован в Динабурге. О, если бы человек был чем-нибудь виноват, не было бы тяжело назначение, но [епитимья] испытывать наказания за то, что Лидскому исправнику не дали угощения... Но что делать, пришли для нас такие прискорбные времена, что и невинные должны терпеть. Мы прибыли в Псков 15-го и должны оставаться до общей отправки. Жизнь нам здесь очень не нравится, все ужасно дорого. Например, фунт черного и не густого хлеба 4 гроша (2 коп. сер.), горшок молока, не имеющего сливок и еще, пожалуй, с водой 10 грошей (5 коп. сер.) мясо фунт 20 грошей (10 коп. сер.). Я помещаюсь отдельно от жены и имею 19 товарищей. У [жены] 7 подруг... Дают нам ежедневно по 20 грошей, квартиру, самовар и прислугу... Мучили нас хорошо; прежде Костуси держали нас под арестом 17 дней и меня после 45 дней и наконец, когда пришла бумага о высылке нас, исправный исправник хотел все устроить так, чтобы мы ничего не знали; прислал почтовую бричку и садись счастливо. Текла вечером узнала об этом и смогла уложить все и продать кой-что, чтобы иметь что-нибудь. Жаловался на несправедливость губернатору, но Чертов, защищая свои подлые идеи, три раза летал в Вильно, докзывая на нас. Все место (городок) обложили различными налогами и обывателей поставили в такое положение, что все, опасаясь быть засаженными под арест, молчат. Имело поступить 20 просьб, но как меня заарестовали, все испугались» (ГАНО, 1863-1864, лл. 50-51 об.).

Путь к месту водворения был тяжел. Один из ссыльных в письме родителям из Тобольска от 24 января 1865 г. рассказывал, что после пятинедельного нахождения в Москве был отправлен в Томскую губернию. Путь пролегал через Нижний Новгород, где ему посчастливилось встретить полковника Арнольда. По этому поводу он указывал, что «рад был видеть его как какого родного» (ГАНО, 1865, л. 77). В Перми он оставался 15 недель, откуда пешком отправлен был по этапу в Тобольск, получая по 16 коп. кормовых. В мемуарах и исследованиях неоднократно упоминалось о милосердном отношении к единоверцам со стороны Тобольского губернатора Деспот-Зеновича. Проявилось оно и в этот раз. Безымянного дворянина решением губернатора временно оставили в Тобольске. Однако и временное послабление было сопряжено с возникающими трудностями, в первую очередь, финансового характера:

«Живу в городе на вольной квартире, плачу в месяц со столом 5 1/2 рублей, кормовых я получаю по 15 коп., что составит в месяц 4 1/2 рубля, а потому кроме чая, которого одну чашку пью сладкого, а другую вприкуску и то утром, вечером же всегда вприкуску, я дожжен ежемесячно добавлять 1 рубль. Кажется, что 
скоро придется оставаться при одном обеде, а вместо чая есть кусок хлеба с водой» (ГАНО, 1865, л. 77 об.).

Новое место жительства создавало ссыльным многочисленные проблемы, прежде всего - коммуникационные. Так, в экстракте одного из писем Эдуарда Миттельтадта Антонию Фибиху, отправленном из с. Спасского Тобольской губернии, отмечался факт проживания особняком по причине незнания русского языка. Поэтому адресант «не мог нигде бывать» (ГАНО, 1865, л. 96). Ситуацию в Спасском, судя по содержанию экстракта, ничуть не улучшало проживание «20 товарищей из Литвы, Волыни и Подольской губернии», между которыми царила «страшная разладица» (ГАНО, 1865, л. 96). Это не способствовало консолидации ссыльных.

Во многих письмах, как ссыльных, так и тех, кто остался на родине, красной нитью проходила мысль о прощении и амнистию. В 1865 г. все взоры были устремлены на наследника цесаревича Николая Александровича, помолвленного с дочерью датского короля принцессой Дагмар. В письме Плятер, например, упоминаются «надежды на прощение высланным в мае месяце (1865 г. - В.Ш.) при бракосочетании Государя Наследника Цесаревича» (ГАНО, 1865, л. 37). Его внезапная кончина в Ницце нашла отклик в среде польских ссыльных. В письме неизвестного автора своей матери из Белозерска от 19 апреля, в частности, отмечается, что

«наследник престола очень худое время выбрал для своей смерти, и для нас ничего не сделал, и манифест наш поехал на тот свет» (ГАНО, 1865, л. 150).

Тема амнистии вновь появилась в письмах в 1867 г. В своем послании матери Николаи в июне 1867 г. выражал надежду скоро встретиться, упоминая о манифесте 17 мая 1867 г. В нем же он предполагал, что «амнистия даст право переселяться в Россию» (ГАНО, 1866-1867, л. 294). Следует отметить, что в польском сознании под Россией подразумевались преимущественно земли времен царствования Ивана IV. Все, что находилось далее на восток, характеризовалось как «Сибирь» - собственно сибирские земли, Урал, Поволжье.

Несмотря на то, что родственники и друзья имели возможность отправлять ссыльным деньги, этих небольших сумм не хватало для проживания на новом месте. Приведенный выше тобольский пример тому лишнее подтверждение. Многие стремились найти заработок. Но законодательно ссыльных было запрещено принимать на государственную и общественную службу. Занятия отдельными видами деятельности (например, фотографированием, содержанием гостиниц и т.д.) тоже табуировались. При благоприятном стечении обстоятельств они могли получить какую-то срочную работу.

Некоторые ссыльные давали частные уроки. Подобного рода заработок в одном из писем характеризовался как единственный способ получить «средства к жизни» (ГАНО, 1865, л. 173). Так, одному из ссыльных посчастливилось стать наставником по рисованию. На это его подтолкнула крайняя нужда, ибо 
с момента прибытия на место ссылки он и жена не получили «ни одного гроша». В своем письме брату он упомянул расценки за урок: «по рублю за час, хорошо бы было, если бы побольше таких часов» (ГАНО, 1865, л. 174 об.). В месяц заработок составлял 9 рублей. Вероятно, несистематические уроки брал кто-то из местных чиновников, увлекавшихся живописью. Владение кистью позволило ему заняться написанием портретов. Однако дело тормозило отсутствие необходимых материалов. Неудивительна просьба, адресованная брату:

«живя ближе к Петербургу (в Новгороде - В.Ш.), может быть, найдешь случай через кого-нибудь для меня несессер с масляными красками» (ГАНО, 1865, л. 174 об.).

Рассчитаться за покупку предполагалось за счет сделанных на заказ работ.

Ссыльные делились информацией о ситуации в своих губерниях. Так, в письме брату, отбывавшему ссылку в Новгороде, Леопольд Щавинский 18 февраля 1867 г. советовал, что «если нет занятий в Новгороде, хлопотать о перемещении в Смоленск» (ГАНО, 1866-1867, л. 139). Материальные трудности усиливали депрессивные настроения. В одном из писем ксендзу Пиотровичу, отбывавшему ссылку в Кириллове на Новгородчине, ксендз Козицкий сообщал о своем прибытии в г. Колывань Томской губернии. Он отметил тот факт, что

«город очень красив, особенно, как говорят, летом, но что в этом, когда каждую минуту испытываешь нужду, из дома нет помощи никакой» (ГАНО, 1865, лл. 97-97 об.).

Обустройство на новом месте жительства было связано не только с материальными трудностями. Глубоко религиозные поляки нуждались в духовной поддержке со стороны католического духовенства. Однако далеко не везде, куда были направлены для водворения, они могли ее получить. Так, Адольф Сумовский в одном из первых своих писем жене в 1867 г. писал, что «в Ачинске ни костела, ни ксендзов нет» (ГАНО, 1866-1867, л. 158 об.).

Неоднократно в переписке ссыльных 1870-1871 гг. встречается упоминание об эпидемии холеры. О ней рассказывали адресатам католический епископ Попель, отбывавший ссылку в Новгороде (ГАНО, 1871, лл. 100, 108, 120), а также ссыльные из Уфимской губернии (ксендзу Затцу писал ксендз Скульский о положении в Бирске в послании от 22 августа 1870 г. (ГАНО, 1870-1871, л. 69); ксендз Боярский, ему же, замечал, что «много умирают холерой, что Станислав два раза заболевал холерой, но спасли его» (ГАНО, 1870-1871, л. 70). Тема не прослеживается в письмах сибиряков, из чего можно сделать вывод, что эпидемия на тот момент миновала сибирский регион.

Среди ослабленных длительным переходом в Сибирь ссыльных распространенными болезнями являлись оспа и тиф. В одном из писем адресант пишет своему брату, что сам он «ни с какой болезнью не знаком - товарищей же много переболело и на оспу и на тиф, в числе которых была и моя жена» (ГАНО, 1865, л. 174). 
Письма позволяют проследить семейную историю. В марте 1867 г. г-жа Сумовская, проживавшая в Новгороде, получила сразу два письма от мужа, которому для отбытия наказания была определена Енисейская губерния. К тому моменту Адольф Сумовский уже проживал в г. Ачинске. Среди прочих был вопрос о её приезде в Сибирь (ГАНО, 1866-1867, л. 158). В одном из писем он извещал жену, что нанял хорошую квартиру и просит скорее уведомить его о своем согласии, чтобы не делать лишних расходов (ГАНО, 1866-1867, л. 165). Зная не понаслышке о транспортных трудностях поездки в Сибирь, он рекомендовал ей, «если получит разрешение ехать, чтобы не ехала во время разлива рек» (ГАНО, 1866-1867, л. 158 об.). Однако уже через несколько недель Адольф просит жену не приезжать в Ачинск. Из экстрактов можно сделать вывод, что она изначально не была намерена разделить участь мужа, получив разрешение, вернуться из Новгорода к детям.

Экстракты создают двойственное впечатление о материальном состоянии семьи Сулимовских. Будучи владельцами имения под Минском, она должна была получать определенный доход. В одном из первых писем Адольф просит жену не продавать имение (ГАНО, 1866-1867, л. 158). Но жизнь в ссылке внесла свои коррективы. И вскоре он просил жену по возможности не продавать имение Поддубы, но, если возникнет необходимость, взять за него не менее 25 тыс. руб. В этом же письме он просит переслать ему 100 или 150 руб. по возможности к 1 марта, обещая деньги эти возвратить в мае. В майском письме того же 1867 г. г-жа Сулимовская извещается о бедственном положении супруга, которое стало причиной неполучения денег в течение 16 недель. «Совершенно остался голым и часто есть нечего», - отмечается в жандармском экстракте (ГАНО, 1866-1867, л. 246).

В августовском письме 1868 г. Адольф сообщает, что в скором времени получит разрешение на выезд из Красноярска в Новгородскую губернию. В нем же указывает, что на переезд получил 400 руб. от Елены (возможно, сестры, которая упоминалась в одном из более ранних писем). Но в этом же письме содержится приписка от некоего Липского. В ней уточняется, что деньги на дорогу находятся у него, «что он не даст их ему (Адольфу - В.Ш., Т.Н.) потому, чтобы он их не тратил» (ГАНО, 1868, л. 4). По всей вероятности, расточительство стало причиной плачевного состояния Сумовского в Ачинске через несколько после прибытия. Ехать в Россию он должен был вместе с ссыльным Пожецким, который испросил право на переселение в Старую Руссу. Липовский отмечал, что «лучшего товарища для Адольфа в дороге, каков Пожецкий, нельзя найти» (ГАНО, 1868, л. 4 об.). Ему, вероятно, предстояло ограничивать траты товарища в пути. 


\section{Стефания Пиоттух и ее «Сибирские» письма}

В сохранившихся канцелярских документах раскрываются и некоторые личные драмы. Одна из них представлена в письмах г-же Платер, отбывавшей ссылку в г. Кириллове Новгородской губернии. Ее адресанты - брат Михаил и подруга Стефания Пиоттух. Последняя, судя по переписке, была влюблена в Михаила Платера и намеревалась выйти за него замуж.

Бывший граф Михаил Ксаверьевич Платер за участие в Январском восстании по приговору военного суда при 27 пехотной дивизии был «лишен всех особенных лично и по состоянии присвоенных прав и преимуществ и графского достоинства» и сослан на жительство в Томскую губернию в 1864 г. (РГИА, 1866-1874, л. 1). Тысячи верст, разделявшие любящих молодых людей, не стали препятствием для выстраивания дальнейших отношений. Стефания принимает решение отправиться в Сибирь. Для получения разрешения требовались веские основания. Для нее таковым стало «желание» отправиться в Томскую губернию к сосланному на поселение брату Станиславу («за нахождение в шайке мятежников и участие в стычках... по конфирмации командующего войсками Виленского военного округа лишен всех особенных прав и преимуществ и сослан на жительство в Томской губернии с 22 сентября 1864 г.» (РГИА, 1866-1874, л. 1 об.)). В мае 1865 г. разрешение Томского губернатора получено через канцелярию Виленского генерал-губернатора (ГАТО, 1865-1866, л. 1). В своем отношении в Томск последний просил об установлении за Стефанией «по прибытии на место полицейского надзора» (ГАТО, 1865-1866, лл. 1-1 об.]. Это стало основанием для перлюстрации ее переписки в дальнейшем.

В конце июня 1865 г. г-жа Платер получает письмо от брата с извещением о прибытии в Томск, который назначен ему в качестве нового места отбытия ссылки (до того момента он находился на поселении в г. Колывань Томской губернии). Вероятно, перевод стал возможен вследствие «поведения хорошего» (ГАТО, 1865, лл. 437, 441, 456, 461). В нем же он пишет, что почти каждую неделю получает письма от Стефании, которая должна выехать к нему 15 июня из Вильно. У последней не было других состоятельных родственников, кроме дяди. Сам Михаил относился к нему с некоторым недоверием, что подтверждает написанная им фраза: «если только дядя исполнит обещание выдать ей деньги» (ГАНО, 1868, л. 8). Но гораздо важнее другой аспект: по сути, Стефания рассчитывала получить деньги на дорогу, в дальнейшем жить с мужем независимо от родственников. Опасения Михаила впоследствии подтвердились. Позднее он писал сестре, что «дядя, обманув Стефанию деньгами, стал человеком очень неблагородным» (ГАНО, 1868, л. 130), а предстоящая свадьба состоится лишь благодаря его «хлопотам».

Финансовый вопрос стал для Стефании существенным, но отнюдь не главным препятствием на пути к любимому человеку. Нужно было добиться разрешения томского губернатора на приезд и проживание во вверенной ему 
губернии. В своем прошении она указала, что хочет следовать в Сибирь не за женихом, но за братом (ГАТО, 1865-1866, л. 1). Это позволило ей получить нужные бумаги.

Путь Стефании в Сибирь оказался непростым. 26 августа 1865 г. она пишет подруге в Кириллов письмо, отправленное из Перми. В нем особо акцентирует внимание на том факте, что «с каждым часом все приближается к Михаилу и цели своей дороги» (ГАНО, 1868, л. 17). В это время она не сообщает о трудностях, с которыми сталкивается в пути:

«До Перми доехала благополучно». Выражает «надежду, что и дальнейшей ее дороге Бог также будет ее хранителем» (ГАНО, 1868, л. 17).

В дороге она знакомится с новыми людьми, которые тоже едут в Сибирь, общается с купцами, возвращающимися с Нижегородской ярмарки. И рассуждает о том, как продолжать путь из Перми в Томск. Первоначальная идея купить тарантас, на нем следовать в Сибирь отвергнута. Она принимает решение ехать на перекладных вместе с новым попутчиком - «молодым человеком, который едет на службу в Иркутск» (ГАНО, 1868, л. 17).

Разные события вносят коррективы в поездку Стефании. В своем августовском письме г-же Платер она высказывает надежду, что «не ранее 23 сентября будет в Томске» (ГАНО, 1868, л. 17). Но к началу октября все еще остается в Тюмени. Ее попутчиками из Перми оказывается семейство Лазаревых. Но общение с ними не может заглушить тоску. Она вновь пишет, что «скучает очень сильно, потому что еще не ранее как через месяц увидит Михаила (Платер)» (ГАНО, 1868, л. 56). В Перми покупается кибитка. Чем дольше продолжается путешествие, тем чаще она обращает внимание на бытовые и прочие неудобства, о чем сообщает подруге. Так, она отмечает факт того, что «на станциях трудно иметь хороший стол» (ГАНО, 1868, л. 56). Из этого можно сделать вывод, что путешествие начинает ее тяготить. Но она не теряет бодрости и в письме отправляет подруге цветок, сорванный на границе между Европой и Азией.

Дальнейший путь к жениху из Тюмени до Томска Стефания проделала на пароходе «Сибиряк», принадлежавшем компании «Дружба». Психологическое состояние путешественницы подорвано длинной дорогой. Ее уже не радует факт поездки. В своем письме она пишет, что «берега наводят скуку, потому что совсем почти не заселены, <..> что находит Сибирь не такой красивой, как описывала госпожа Цецилия» (ГАНО, 1868, л. 136), а в день именин подруги она «очень скучала». Не добавляет радости и погода, которая, как отмечает корреспондент, «очень холодна». Единственным позитивным событием за время поездки стало наблюдение за загрузкой пароходов дровами, эту картину она назвала «очень живописной».

Завершение путешествия в Томске вызвало у Стефании противоречивые чувства. Несмотря на то, что Михаил с нетерпением ждал невесту, ее прибытие 
Journal of Frontier Studies. 2022. No 1 | ISSN: 2500-0225

Empire in a Personal Dimension | https://doi.org/10.46539/jfs.v7i1.380

на пароходе Сибиряк оказалось для него неожиданным. Этот факт она не преминула отметить в своем письме подруге. С другой стороны, она смогла обрести частичный духовный покой. Об этом свидетельствует упоминание о посещении томского костела, описание которого содержится в письме.

Проживание в Томске - очередное испытание. Сразу по прибытии Стефанию селят в доме Томашевых, где ее навещает Михаил. С одной стороны, она желает «скорее быть хозяйкой» (выйти замуж - В.Ш., Т.Н.), а с другой - в ее мыслях господствует неуверенность, ибо «она не знает, в состоянии ли будет своими пожертвованиями счастливить Михаила» (ГАНО, 1868, л. 170). В его любви она нисколько не сомневается, о чем и пишет подруге в Кириллов.

В нарушение всех норм приличия того времени Стефания уже через месяц после приезда в Томск оставляет приютивших ее Тимашевых и поселяется с избранником. На это указывает содержание письма, полученного г-жой Платер 10 декабря. В нем Стефания пишет о том, что проживает вместе с Михаилом в квартире «хорошенькой, но маленькой».

В этом письме впервые отражается трагедия молодой женщины, отправившейся за любимым в Сибирь, чтобы выйти за него замуж. Она оказывается рядом с совершенно иным, переродившимся человеком. Теперь женщина заявляет о том, что «нашла и находит Михаила... совсем другим; что он очень не любезен, даже груб» (ГАНО, 1868, л. 175). Его интересуют только цифры и счета. Ситуацию усугубляет сложное материальное положение, которое не позволяет нанять прислугу. Теперь Стефания не просто хозяйка дома, она вынуждена самостоятельно вести хозяйство, заниматься всеми бытовыми делами. Психика не оправившейся от тяжелой дороги женщины надломлена. Подруге она пишет, что «сильно разочарована предстоящей будущностью и видит пред собою пропасть, в которую добровольно должна броситься» (ГАНО, 1868, л. 175). Кризис усугубляет болезнь, обусловленная последствиями акклиматизации. Стефания прекрасно понимает свою зависимость от Михаила, а потому просит в своих письмах ничего об этом ему не сообщать.

В своем следующем послании (отправлено из Томска 22 ноября, получено в Канцелярии Новгородского губернатора 18 декабря) женщина именует себя «бедной и разочарованной» (ГАНО, 1868, л. 176). В своих прежних письмах, написанных по пути в Сибирь, она считала часы до встречи с любимым, теперь «каждая новая минута [рядом с Михаилом] наносит... новую рану в сердце» (ГАНО, 1868, л. 176). Содержание этого письма настолько проникнуто болью, что капитан Леохновский выполнил дословный перевод:

«Моя любовь и самопожертвование не имеют награды. Перестаю даже думать, что он любит меня. Оставить родину, родных, все, надеясь на лучшее будущее, все пожертвовать для любви и не видеть ни внимания, ни сочувствия - ужасно! О! Предо мною тяжелая - тяжелая жизнь, но жить должна. Должна выпить чашу горести до дна. Я не могу спать от боли сердца. Вместо любви ко мне Михаил требует, чтобы я была купцом, спекулянтом - как он. Не знаю, что из меня будет. Слезы не высыхают на моих глазах» (ГАНО, 1868, л. 176). 
Некогда любимый человек превратил Стефанию в домработницу. Нанята кухарка - лишь для того, чтобы готовить обеды: «будут постоянно обедать за плату трое» (ГАНО, 1868, л. 176). Ей уготована и роль хозяйки салона, ибо она должна развлекать для привлечения в контору клиентов, которых Михаил приводит в гости. В очередной раз она сетует подруге на безвыходность своей ситуации: «воротиться [на родину она] не имеет права» (ГАНО, 1868, л. 176 об.), а потому вынуждена связать свою дальнейшую судьбу с Платером.

\section{Выводы}

В условиях борьбы с нараставшим национально-освободительным и революционным движением власть предпринимала различные меры по контролю над ссыльными. Одной из таких форм стала перлюстрация писем лиц, находившихся под полицейским надзором. К концу 1863 г. выработан механизм контроля за почтовой и телеграфной корреспонденцией части польских ссыльных. Ответственность за ознакомление с ее содержанием была возложена на наиболее благонадежных чиновников, пользовавшихся безусловным доверием губернаторов и владевших польским языком. Подобный просмотр продолжался почти десять лет. Только 27 апреля 1873 г. по докладу Министра внутренних дел А.Е. Тимашева последовала резолюция Александра II: просмотр корреспонденции поляков, высланных по политическим причинам из Царства Польского и Западного края и находящихся под надзором полиции в Европейской России, прекратить (РГИА, 1863-1873, л. 244).

Новгородская коллекция экстрактов и копий писем польских ссыльных, их родных и близких содержит разноплановую информацию о повседневной жизни, оценках событий общегосударственного и местного значения. Осознавая факт перлюстрации корреспонденции, адресанты стремились к такому изложению своей жизни, чтобы у чиновников при губернаторской канцелярии не было повода отказать в ее отправлении, а адресат мог получить его с пометкой, что «письмо не заключает в себе ничего, что могло бы препятствовать выдаче его по адресу». Несомненно, этот источник является слабоиспользованным, но информативным. Дальнейшее изучение выявленных экстрактов и копий писем позволит более рельефно представить жизнь польских ссыльных в 1864-1873 гг.

\section{Благодарности}

Исследование выполнено при финансовой поддержке РФФИ и БРФФИ в рамках научного проекта № 20-59-00010 «Этнические меньшинства в Беларуси и России в условиях общественных трансформаций XIX-XX вв.». 
The reported study was funded by RFBR and BRFBR, project number 20-59-00010 "Ethnic minorities in Belarus and Russia in the conditions of social transformations of the XIX-XX centuries".

\section{Список литературы}

Daly, J. W. (1998). Autocracy under siege: Security police and opposition in Russia, 1866-1905. Northern Illinois University Press.

Lauchlan, I. (2002). Russian Hide-and-Seek: The tsarist secret police in St Petersburg, 1906-1914. Suomalaisen Kirjallisuuden Seura - Finnish Literature Society.

Schleifman, N. (1988). Undercover agents in the Russian revolutionary movement: The SR party, 19021914. St. Martin's Press.

Sinko, G. I., \& Shaidurov, V. N. (2021). State Policy Towards the Participants of the Polish Uprising of 1863-1864: The Novgorod Exile of the Catholic Bishop Vikenty Theophil Popel. Bylye Gody, 16(1). https://doi.org/10.13187/bg.2021.1.262

Stanton, M. D. (1992). The Time Line and the "Why Now?" Question: A Technique and Rationale for Therapy, Training, Organizational Consultation and Research. Journal of Marital and Family Therapy, 18(4), 331-343. https://doi.org/10.1111/j.1752-0606.1992.tb00947.x

Zukerman, F. (1996). The Tsarist Secret Police in Russia Society, 1880-1917. New York.

Алексеева, М. А. (2013). Повседневная жизнь польских политических ссыльных в Новгородской губернии во второй половине XIX века. В Б. Н. Ковалев (Ред.), К 150-летию Январского восстания в Польше: Польские ссыльные в Новгородской губернии. Материалы международной научной конференции (сс. 84-90). Великий Новгород.

Аракелян, М. А. (2007). Перлюстрация как метод политического сыска в конце XIX - начале XX веков. Вестник Саратовского государственного сощиально-экономического университета, 5, 127-130.

Бодунова, О. Г. (2014). Перлюстрация в деятельности полиции по раскрытию преступлений террористического характера во второй половине XIX века. Российский следователь, 12, $53-56$.

Гончарова, Е. А. (2008). Система перлюстрации в России в конце XIX-начале XX в. Вопросы Истории, 1, 96-102.

Горбачева, И. М. (2015). Перлюстрация как метод борьбы политической полиции с революционным движением во второй половине XIX в. Экономические и социально-гуманитарные исследования, 1, 105-109.

Государственный архив Новгородской области (ГАНО). (1863-1864). Ф. 138. Оп. 1. Д. 2286.

Государственный архив Новгородской области (ГАНО). (1865). Ф. 138. On. 1. Д. 2360. (In Russian).

Государственный архив Новгородской области (ГАНО). (1866-1867). Ф. 138. Оп. 1. Д. 2478. (In Russian).

Государственный архив Новгородской области (ГАНО). (1868). Ф. 138. On. 1. Д. 2506. (In Russian).

Государственный архив Новгородской области (ГАНО). (1870-1871). Ф. 138. Оп. 1. Д. 2594.

(In Russian). 
Государственный архив Новгородской области (ГАНО). (1871). Ф. 138. On. 1. Д. 2627. (In Russian).

Государственный архив Томской области (ГАТО). (1865). Ф. 3. Ол. 2. Д. 1041.

Государственный архив Томской области (ГАТО). (1865-1866). Ф. 3. Ол. 54. Д. 536.

Кеклис, А. Ю. (2009). Законодательное регулирование перлюстрации в Российской империи XIX - начала XX веков. История государства и права, 4, 23-25.

Ковалев, Б. Н. (2013). Архиепископ Плоцкий и Варшавский Феофил Винсент Попель: Семь лет ссылки в Новгород в перлюстрированной переписке и жандармских документах. В Б. Н. Ковалев (Ред.), К 150-летию Январского восстания в Польше: Польские ссыльные в Новгородской губернии. Материалы международной научной конференщии (сс. 44-54). Великий Новгород.

Любичанковский, С. В. (2009). Общество и власть в России начала XX века (по материалам перлюстрации). Вестник Нижневартовского государственного гуманитарного универсиmema, 2, 65-70.

Полное собрание законов Российской илперии. Издание II (ПСЗ-II). Т. 1. № 313. (б. д.).

Путрова, Е. А. (2017). Перлюстрация корреспонденции как способ надзора над политической ситуацией во второй половине XIX века (на примере Смоленской губернии). В Славянский мир: Письменность, культура, история. Материалы научно-практической конференции (сс. 106-111). Смоленский государственный институт искусств.

Российский государственный исторический архив (РГИА). (1863). Ф. 1282. Оп. 1. Д. 129.

Российский государственный исторический архив (РГИА). (1866). Ф. 1286. Оп. 27. Д. 1101.

\section{References}

Alekseeva, M. A. (2013). Everyday life of Polish political exiles in Novgorod Province in the second half of the 19th century. In B. N. Kovalev (Ed.), On the 150th anniversary of the January Uprising in Poland: Polish Exiles in Novgorod Province. Proceedings of an international scientific conference (pp. 84-90). Veliky Novgorod. (In Russian).

Arakelyan, M. A. (2007). Perlustration as a method of political surveillance in the late 19th and early 20th centuries. Bulletin of Saratov State Social and Economic University, 5, 127-130. (In Russian).

Bodunova, O. G. (2014). Perlustration in police work to solve terrorist crimes in the second half of the 19th century. Russian investigator, 12, 53-56. (In Russian).

Complete Collection of Laws of the Russian Empire. Edition II. Vol. 1. No 313. (n. d.). (In Russian).

Daly, J. W. (1998). Autocracy under siege: Security police and opposition in Russia, 1866-1905. Northern Illinois University Press.

Goncharova, E. A. (2008). The system of perlustration in Russia in the late 19th-early 20th century. History Issues, 1, 96-102. (In Russian).

Gorbacheva, I. M. (2015). Perlustration as a method of political police struggle against revolutionary movement in the second half of the 19th century. Economic and social-humanitarian studies, 1 , 105-109. (In Russian). 
Keklis, A. Y. (2009). Legislative regulation of perlustration in the Russian Empire of the 19th early 20th centuries. History of the State and Law, 4, 23-25. (In Russian).

Kovalev, B. N. (2013). Archbishop Theophilus of Płock and Warsaw Vincent Popiel: Seven Years of Exile in Novgorod in Perlustrated Correspondence and Gendarme Documents. In B. N. Kovalev (Ed.), On the 150th anniversary of the January Uprising in Poland: Polish Exiles in Novgorod Province. Proceedings of an international scientific conference (pp. 44-54). Veliky Novgorod. (In Russian).

Lauchlan, I. (2002). Russian Hide-and-Seek: The tsarist secret police in St Petersburg, 1906-1914. Suomalaisen Kirjallisuuden Seura - Finnish Literature Society.

Lubichankovsky, S. V. (2009). Society and Power in Russia in the Early Twentieth Century (Based on the Materials of Perlusion). Bulletin of the Nizhnevartovsk State Humanitarian University, 2, 65-70. (In Russian).

Putrova, E. A. (2017). Correspondence Perlusion as a Way of Political Surveillance in the Second Half of the 19th Century (Case Study of Smolensk Province). In Slavic World: Writing, Culture, History. Materials of the scientific-practical conference (pp. 106-111). Smolensk State Institute of Arts. (In Russian).

Russian State Historical Archive (RSHA). (1863). F. 1282. In. 1. C. 129. (In Russian).

Russian State Historical Archive (RSHA). (1866). F. 1286. In. 27. C. 1101. (In Russian).

Schleifman, N. (1988). Undercover agents in the Russian revolutionary movement: The SR party, 1902-1914. St. Martin's Press.

Sinko, G. I., \& Shaidurov, V. N. (2021). State Policy Towards the Participants of the Polish Uprising of 1863-1864: The Novgorod Exile of the Catholic Bishop Vikenty Theophil Popel. Bylye Gody, 16(1). https://doi.org/10.13187/bg.2021.1.262

Stanton, M. D. (1992). The Time Line and the "Why Now?" Question: A Technique and Rationale for Therapy, Training, Organizational Consultation and Research. Journal of Marital and Family Therapy, 18(4), 331-343. https://doi.org/10.1111/j.1752-0606.1992.tb00947.x

State Archive of the Novgorod Region (SANR). (1863-1864). F. 138. In. 1. C. 2286.

State Archive of the Novgorod Region (SANR). (1865). F. 138. In. 1. C. 2360. (In Russian).

State Archive of the Novgorod Region (SANR). (1866-1867). F. 138. In. 1. C. 2478. (In Russian).

State Archive of the Novgorod Region (SANR). (1868). F. 138. In. 1. C. 2506. (In Russian).

State Archive of the Novgorod Region (SANR). (1870-1871). F. 138. In. 1. C. 2594. (In Russian).

State Archive of the Novgorod Region (SANR). (1871). F. 138. In. 1. C. 2627. (In Russian).

State Archive of Tomsk Oblast (SATO). (1865-1866). F. 3. In. 54. C. 536. (In Russian).

State Archive of Tomsk Oblast (SATO). (1865). F. 3. In. 2. C. 1041. (In Russian).

Zukerman, F. (1996). The Tsarist Secret Police in Russia Society, 1880-1917. New York. 